\title{
'Wit' armoede en 'wit' bevoorregting in enkele Afrikaanse jeugromans
}

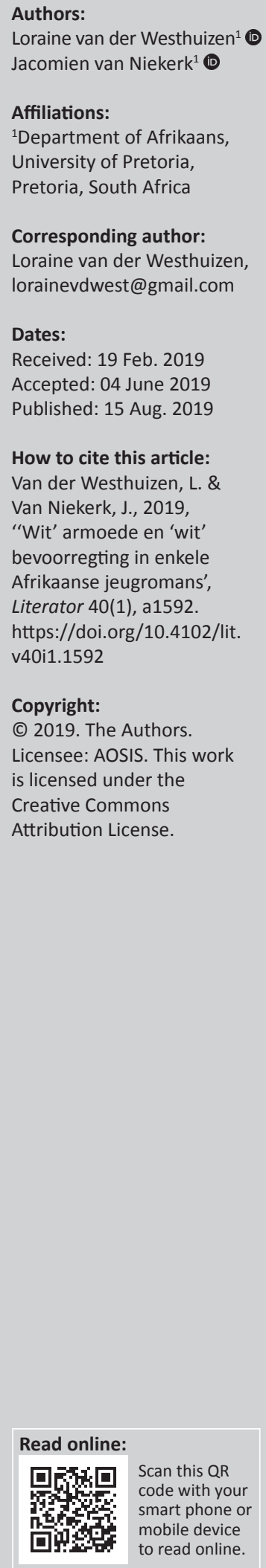

'White' poverty and 'white' privilege in selected Afrikaans novels for young adults. This article examines the representation of 'white' poverty in selected Afrikaans novels for young adults published between 1990 and 2014: Droomwa (1990) by Barrie Hough, Die optog van die aftjoppers (1994) by George Weideman, Vaselinetjie (2004) by Anoeschka von Meck, Roepman (2004) by Jan van Tonder, Lien se lankstaanskoene (2008) by Derick van der Walt and Iewers vlieg daar fairy dust (2014) by Marisa Haasbroek. In these novels, poverty functions as a feature of the so-called problem book and coming of age novel. The novels are analysed, however, by employing critical whiteness studies as an overarching theoretical framework. Indicators of the 'white' characters' poverty are identified with regard to description, dialogue, actions and place with the aim of determining how and why these representations are evident in the novels. Apartheid is the backdrop for two of the novels; here, 'white' poverty is portrayed in a nostalgic manner. In the other novels, 'white' poverty is portrayed as irreconcilable with 'whiteness'; 'white' privilege prevails.

Keywords: Afrikaans literature; critical whiteness studies; discourse; poor white problem; poverty; post-apartheid literature; representation; South African literature; whiteness; youth literature.

\section{Inleiding}

In hierdie artikel word ses Afrikaanse jeugromans bestudeer waarin die armoede van die 'wit'1 hoofkarakter(s) 'n prominente tema is: Droomwa (1990) deur Barrie Hough, Die optog van die aftjoppers (1994) deur George Weideman, Vaselinetjie (2004) deur Anoeshka von Meck, Roepman (2004) deur Jan van Tonder, Lien se lankstaanskoene (2008) deur Derick van der Walt en Iewers vlieg daar fairy dust (2014) deur Marisa Haasbroek. Hierdie romans is almal 'probleemboeke'2 én coming of age-romans. 'Wit' armoede en 'n stel probleme daarmee gepaardgaande vorm die agtergrond waarteen die hoofkarakters puberteit en volwassenheid bereik. Die karakters word van hulle 'onskuld' ontneem deur die struikelblokke wat spesifiek as gevolg van hul armoede veroorsaak word. In Droomwa, Die optog van die aftjoppers en Iewers vlieg daar fairy dust is die dood van een of albei ouers die rede vir 'wit' karakters se armoede, en in Lien se lankstaanskoene is dit haar pa se tronkstraf vir bedrog. Roepman is die enigste roman waarin karakters nie skielik in armoede gedompel word nie.

Arm 'wit' karakters is al van baie vroeg af in die Afrikaanse letterkunde teenwoordig, insluitende jeugliteratuur ${ }^{3}$ en sogenaamde 'oorgrenstekste': jeugboeke wat ook deur volwassenes gelees word. Die vroegste voorbeeld is waarskynlik D.F. Malherbe se historiese roman, Vergeet nie (1913) waarin 'n ellendige oorlogsituasie uitgebeeld word. Jochem van Bruggen se Ampie-trilogie (Ampie: die natuurkind 1924, Ampie: die meisiekind 1928 en Ampie: die kind 1942), is vroeë voorbeelde van oorgrenstekste, en is 'die seminale uitbeelding in die Afrikaanse romankuns van die probleem

1. Ras' is 'n konstruksie en hoewel terme soos 'wit' en 'swart' algemeen gebruik word, bestaan daar nie iets soos'n biologiese ras nie. Die diskoers van 'ras' word eerder met hierdie terme versterk as ondermyn. Die terme ('wit', 'swart', 'bruin', 'ras' en 'witheid') word in hierdie artikel in aanhalingstekens geplaas om aan te toon dat dit die gangbare adjektief vir mense se velkleur is, maar dat dit nie as letterlik of vanselfsprekend aanvaar word nie.

2.Volgens Van den Hoven (1994)

wordt het probleemboek geplaatst binnen het realistische genre: de werkelijkheid buiten het boek wordt, weliswaar in verdichte vorm, zo realistisch mogelijk uitgebeeld, met de nadruk op een of vaak meerdere problemen en conflicten waarvoor de jonge hoofdpersoon komt te staan. (bl. 39)

3.'n Kwessie waaroor daar al gedebatteer is, is watter term gebruik moet word vir fiksie wat op die ouderdomsgroep gemik is wat nie meer kinderliteratuur lees nie, maar ook nie volwasse literatuur nie (vgl. onder andere Nieman 2005; Oosthuizen 2010 en Sturm \& Michel 2009). Rhebergen en Human (2015) gebruik die term 'jeugliteratuur' en definieer dit as 'literatuur wat hoofsaaklik, maar nie eksklusief nie, gemik is op lesers van tussen ongeveer 13 en 18'. Van der Walt (2012) se gebruik van die term fiksie vir jong volwassenes $(\mathrm{FJV})$ is ' $\mathrm{n}$ doelbewuste navolging van die Amerikaanse 'Young Adults'-genre (YA). Williams (2014) argumenteer dat tienerfiksie

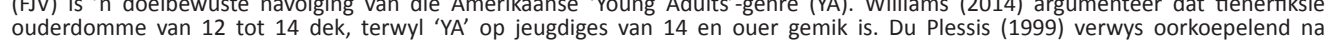
'jeuglektuur', wat na ons mening uitruilbaar met 'jeugliteratuur' aangewend kan word. Volgens ons is al die gekose romans op lesers tussen die ouderdom van 12 en 21 gemik. Die romans bevat ook 'volwasse' temas. Ons gebruik dus in hierdie artikel 'jeugliteratuur' as 'n oorkoepelende term wat Van der Walt (2012) se 'FJV' insluit. 
van die armoede van wit Afrikaners en die sogenaamde armblankeprobleem in die twintiger- en dertigerjare in SuidAfrika' (Botha 1999:646).

Die 'armblankeprobleem' of 'armblankevraagstuk', die verskynsel van groot hoeveelhede 'wit' mense wat in armoede verkeer, was in die jare dertig van die twintigste eeu iets wat in Suid-Afrika en die Verenigde State van Amerika die ingryping van die Carnegiekommissie voorafgegaan het. In die kommissie se verslae is verskillende tipes 'armblankes' geïdentifiseer met betrekking tot die manier waarop hulle in armoede verval het. Volgens Giliomee (2004:68-69) het hierdie redes beteken '[armoede] was nie 'n probleem waaroor die armes self verantwoordelik gehou kon word nie, maar die gevolg van maatskaplike en ekonomiese prosesse waaroor hulle min beheer gehad het'. Willoughby-Herard (2003:68-69) neem 'n meer kritiese ingesteldheid teenoor die Carnegie-verslae in: die 'armblankevraagstuk' in Amerika en Suid-Afrika was in die eerste plek 'n 'vraagstuk' aangesien 'witheid' as onversoenbaar met die vernedering en ontberings van armoede beskou is. Hoewel die verslae dus voorgee om 'n strukturele verklaring vir armoede te verskaf, berus hulle verklarings op die 'racial logic' dat 'wit' armoede 'n unieke verskynsel is (Willoughby-Herard 2003:68-69). In werklikheid was arm 'wit' mense wat noue interaksie met armes van alle velkleure gehad het, 'n bedreiging vir die dogma van 'wit' superioriteit. Willoughby-Herard (2003:20-21) stel dit soos volg:

The focus on poor whites and the vulnerability of white civilization in South Africa to degeneration and 'going native' becomes the foundation for grand apartheid. Grand apartheid, it was believed, would uplift a section of the white community that had come to be represented as a 'waste of white skin'.

'Wit' armoede is nie 'n neutrale verskynsel nie, en dit kan gevolglik ook nie in literêre tekste as neutraal hanteer word nie. Afrikaanse literêre tekste waarin armoede prominent is, moet gevolglik altyd binne die diskoers oor 'wit' armoede, insluitende die 'armblankevraagstuk' en die ideologiese implikasies daarvan, gesitueer word. 'Witheid' word immers hoofsaaklik met bevoorregting, insluitende rykdom, aansien en geleenthede geassosieer (Lipsitz 2006:vii). In Suid-Afrika leef minder as $1 \%$ van 'wit' mense in armoede teenoor $46,6 \%$ van 'swart' mense (Wilkinson 2018).

Die artikel verskaf eerstens 'n kort oorsig oor Afrikaanse literêre tekste (jeugliteratuur en 'volwasse' literatuur) wat oor 'wit' armoede handel. Dan word die gekose jeugromans onder die loep geneem. Die gegewe van 'wit' karakters se armoede word op basiese verhaalvlakke nagespeur: beskrywing, optrede, dialoog, ruimte, en vertelling. Hoe word die armoede van 'wit' karakters in die romans gerepresenteer? Hoe word die 'wit' karakters as arm gerepresenteer? Ons verwys telkens na die 'merkers' van armoede in die tekste. Die romans is tussen 1990 tot 2014 gepubliseer, dit wil sê te midde van en ná die politieke wending in Suid-Afrika vanaf die vrylating van Nelson Mandela in 1990. Wybenga and Snyman (2005:25) beweer 'die verandering wat sedert die 1960's by Afrikaanse literatuur vir volwassenes ingetree het, het eers heelwat later gekom vir die kinder- en jeugliteratuur'. 'n Nuwe geslag skrywers tree in 1990 na vore en dit is asof 'n breuk met die verlede in hul skryfwerk op politieke vlak en ten opsigte van ander taboes gesien word (Wybenga \& Snyman 2005:27). Oosthuizen (2010:63) beweer 1990 is die datum 'van waar daar duidelike en betekenisvolle veranderinge in onder andere die produksie, verspreiding en aankoop van kinderliteratuur waargeneem kan word'. Droomwa en Roepman speel vóór 1990 af en Die optog van die aftjoppers, Vaselinetjie, Lien se lankstaanskoene en Iewers vlieg daar fairy dust ná 1990.

Selfs wanneer tekste oënskynlik oor arm 'wit' mense handel, is dit 'n geldige hipotese dat 'wit' bevoorregting ' $n$ rol in die tekste sal speel. Nadat die merkers van armoede by die 'wit' karakters dus geïdentifiseer en ontleed is, ondersoek hierdie artikel ook die verskynsel van 'wit' bevoorregting in die gekose tekste. Soos hierbo genoem, is beoefenaars van kritiese witheidstudies skepties teenoor 'n konsep soos 'wit' armoede, aangesien 'witheid' onmiskenbaar met bevoorregting verbonde is. Die nostalgiese representasie van die 'witheid' in en die verlede in Droomwa en Roepman kom hier aan bod.

Droomwa (1990) deur Barrie Hough speel in die 1960's af en handel oor die hoofkarakter, Paul en sy gesin. Na die dood van Paul se pa moet die gesin van hul huis in 'n gegoede buurt in Johannesburg na 'n woonstel in Hillbrow trek. Die ontvangs vir hierdie roman is oorwegend gunstig (kyk bv. Anon. 1991; Cilliers 1990; Konterdans 1990; Le Roux 1990; Minervini 1990; Steenberg 1990). Hough kry ook aandag van die Engelse pers (De Waal 1994; Garson 1991; Vinassa 1991) aangesien Droomwa in Engels as Dream chariot (1993) uitgegee is. Hough ontvang die Sanlam-prys vir Jeuglektuur (Silwer), die Alba Bouwer-Prys vir Kinderlektuur en die C.P. Hoogenhout-toekenning vir hierdie roman.

George Weideman se Die optog van die aftjoppers (1994) handel oor Jacques en sy ma, Anna, na sy pa se dood in 'n fratsongeluk op die treinspoor. Dit is die 1990's en Jacques reël 'n buitengewone optog vir die skool se entrepeneurswedstryd, wat bestaan uit deelnemers wat hoofsaaklik arm is en uit die sentrum van bestaan gewerp is. Die roman word gunstig deur Hough (1994), Le Roux (1994) en Steenberg (1995) geresenseer. Vir hierdie roman ontvang Weideman die Sanlam-prys (Goud) en die Scheepers-prys vir Jeuglektuur.

Vaselinetjie (2004) deur Anoeschka von Meck handel oor die grootwordjare van die hoofkarakter met dieselfde naam. Die roman is meestal ongunstig deur Olivier 2005 en Jacobs 2004 en gunstig deur Brümmer (2004) geresenseer. Olivier (2005:13) meen 'baie van die potensiële verhoudingspannings word nie uitgebou nie en sekere belangrike episodes word simplisties aangebied'. Vir Jacobs (2004:6) gee Von Meck 'by meer as een geleentheid toe aan die verleiding van sentiment en moralisasie'. Von Meck word nogtans met die M.E.R.-prys 
vir Jeuglektuur, die Jan Rabie/Rapport-Prys en die M-Netprys (kort formaat) bekroon. Die roman word ook op die ererol van die International Board on books for young people (IBBY) in Suid-Afrika geplaas. Die roman is in Engels as My name is Vaselinetjie (2009) uitgegee. Marguerite van Eden en Nicole Bond vertolk die hoofkarakter in Vaselinetjie, 'n rolprent wat met Corné van Rooyen as regisseur in 2017 verskyn.

Die oorgrensroman Roepman (2004) deur Jan van Tonder speel in 1966 af en beeld die grootwordjare van Timus as deel van 'n arm gesin in 'n Durbanse spoorweghuis uit. Die roman is oorheersend gunstig ontvang (kyk Cilliers 2005; Hambidge 2004; John 2005; Van Wyk 2004). Roepman is in Engels as Stargazer (2006) uitgegee (gunstig deur Murphy in 2006 geresenseer), en 'n rolprent is in 2011 vrygestel waarin Paul Loots die hoofrol vertolk met Paul Eilers as regisseur.

Derick van der Walt publiseer in 2008 Lien se lankstaanskoene, 'n roman wat in die onlangse verlede van die 2000's afspeel. Dit is ' $n$ jaar sedert Lien se pa tronkstraf opgelê is vir bedrog, en Lien droom uitsluitlik daarvan om ná matriek oorsee te gaan en Suid-Afrika vir altyd te verlaat. Sy probeer dit doen deur eers by 'n koffiewinkel te werk waar sy nie met die eienares oor die weg kom nie, en 'n haarsalon waar sy baie min verdien, maar kies later om by 'n verkeerslig te begin bedel. Hierdie roman word oorwegend gunstig deur Harper (2009) en Boeke-Insig (Anon. 2009:44) ontvang. Van der Walt verower die Sanlam-prys (Goud) en die M.E.R.-prys vir Jeuglektuur en die roman word op die 2010 ererol van die IBBY geplaas. In 2013 verskyn die rolprent waarin Carmen Pretorius die hoofrol vertolk met André Odendaal as regisseur.

Iewers vlieg daar fairy dust (2014) deur Marisa Haasbroek speel ook in die onlangse verlede af. Die hoofkarakter, Elmien, woon saam met haar ouma en twee niggies in ' $n$ hoofsaaklike 'wit' plakkerskamp in Pretoria. Elmien droom daarvan om eendag ' $n$ mediese dokter te word. Hierdie roman word oorwegend gunstig deur Swart (2014) en Du Toit (2017) ontvang. Haasbroek verower die 2015 ATKV-Woordveertjie in die Selfleeskategorie vir Graad 8 tot 10 vir hierdie roman.

\section{'Witheid', armoede en bevoorregting}

Postkoloniale teorie en kritiese witheidstudies is teoretiese raamwerke waarin die beoefening van mag en diskoers in 'n sosiale sisteem ondersoek kan word. Postkolonialisme (as teorie en praktyk) staan sentraal in die navorsingsveld 'kritiese witheidstudies' (West 2009:12). In die vroeë een-entwintigste eeu is dit nie slegs meer die koloniale subjek wat bestudeer word nie, maar ook verskillende vorme van 'postempire, post-mastery whitenesses attempting to examine themselves in relation to histories of oppression and hegemony of their others' (Lopez 2005:6). Die armoede wat in hierdie artikel bestudeer word, is baie spesifiek 'wit' armoede, en dit noop 'n mens om 'witheid' in die gebeure te ontleed op grond van die psigologiese, kulturele, politiese en ekonomiese dimensies van die bevoorregte posisionering van 'witheid' (Steyn 2001:121). Kritiese witheidstudies is 'n veld wat slegs teen die einde van die twintigste eeu akademiese aandag begin geniet het. Voorheen is 'witheid' as die norm beskou, wat gelei het tot die opvatting dat dit onnodig is om dit afsonderlik te definieer of te bestudeer (Steyn 2001:162-163).

Kritiese witheidstudies bevraagteken die sogenaamde onsigbaarheid van 'witheid' en wil dit uitdaag en ondermyn (Van der Westhuizen 2015:22). 'Witheid' het min te make met pigmentasie, en is eerder 'n identifikasie wat op die historiese feit berus dat 'wit' setlaars (hoofsaaklik van Europese afkoms) groot gedeeltes van die res van die wêreld gekoloniseer het (West 2009:11). West (2009:11) argumenteer dat 'witheid' 'n ongelyke verhouding tussen die 'lighterskinned settler' en die 'darker-skinned native', en so ook die afstammelinge van hierdie setlaars en 'natives' te weeg gebring het. Die geskiedenis van hierdie verhouding in SuidAfrika is duidelik meer gelaai, aangesien dit meer onlangs as in ander gekoloniseerde lande plaasgevind het (West 2009:11). Daar is toenemende weerstand teen die 'taken-forgranted privileges of being at the centre of power' van 'wit' mense (Steyn 2001:119).

Die ruimte ontbreek om in die relevante sosiologiese en ekonomiese literatuur te delf, maar dit is al dekades lank moeilik om armoede bevredigend te definieer (vgl. Alcock 2006:64). Daar is al gepoog om te onderskei tussen absolute armoede en relatiewe armoede: absolute armoede verwys na dit wat nodig is om te oorleef (subsistence) (Alcock 2006:64-65), dit wil sê die armoedsgrens. Relatiewe armoede, daarteenoor, behels 'n vergelyking tussen die lewenstandaard van lede van die samelewing wat nié arm is nie met die lewenstandaard van armes (Alcock 2006:65). Hierdie onderskeid is egter nie onproblematies nie (Alcock 2006:66). Ander terminologie wat aangewend kan word, is objektiewe armoede teenoor subjektiewe armoede. Wanneer iemand hulself as arm beskou ten opsigte van ' $n$ bepaalde verwysingsgroep, beleef daardie persoon subjektiewe armoede - sonder dat die armoedsgrens ' $n$ rol hoef te speel (Ravallion in Fransman \& Yu 2019:50).

Die nuutste tendens ten opsigte van die bepaling van wie objektief gesproke arm is, is die multi-dimensionele benadering - vergelyk onder andere Alcock (2006:78-80) en Fransman en Yu (2019). Volgens hierdie benadering word die gelyktydige ontberings (deprivations) wat iemand beleef in berekening gebring wanneer statistieke oor armoede ingesamel word. Om in 'n informele woning soos 'n karavaan te bly, of om nie 'n radio, televisie, yskas of selfoon te besit nie, is twee van die ontberings wat Fransman en $\mathrm{Yu}$ in hul studie insluit, maar albei dra 'n kleiner gewig as die gebrek aan skoolopvoeding, kindersterftes of gestremdheid. Dieselfde geld vir oorbewoning, wanneer daar meer as twee persone per slaapkamer is (Fransman \& Yu 2019:55). 
In die romans onder bespreking is daar sprake van bogenoemde ontberings ten opsigte van behuising, besittings en oorbewoning. In al die romans is daar definitief sprake van subjektiewe armoede en om daardie rede het ons nie in hierdie artikel die woord armoede in aanhalingstekens geplaas nie. Die verskynsel van 'wit' armoede onder Afrikaners (of 'wit' Afrikaanssprekendes) tydens en ná apartheid, al is dit uiters beperk, kompliseer die diskoers oor 'wit' bevoorregting.

Peggy McIntosh het in 1988 begin nadink oor 'wit' bevoorregting as 'n verskynsel wat soortgelyk is aan manlike bevoorregting (male privilege). In haar besinnende, outobiografiese bydraes hieroor skryf sy onder andere: 'I see a pattern running through the matrix of white privilege, a pattern of assumptions which were passed on to me as a white person [...]' (McIntosh 1989:11). Elders omskryf sy 'wit' bevoorregting kortom as 'unearned advantage' (McIntosh 2015:244). Baie navorsers en mense in die praktyk het al gebruik gemaak van McIntosh se konsep (en die vraelys wat daarmee gepaard gaan) van 'wit' bevoorregting as 'n onsigbare rugsak (knapsack) wat 'wit' mense met hulle saamdra. Willoughby-Herard (2015:90, 225) voer die teenoorgestelde argument: vir haar is 'wit' bevoorregting uiters sigbaar:

Scrutinized by nonwhites, contested by 'lesser whites', and constitutive of the major mediating frames for discourse about all manner of social crises, whiteness propels sensible people to consider who it is that can't perceive white privilege ... Though scholars define whiteness as naturalized property rights and invisible privilege ... white privilege is embodied, highly visible, and associated with the risk of proximity to blackness by which it is defined.

\section{'Wit' armoede in Afrikaanse (jeug)literatuur}

Ná Ampie word 'wit' armoede in jeugromans soos die Trompie-boeke (1950-1957 en 1962-1963) deur Topsy Smith aangetref. Engela van Rooyen se oeuvre - Gesie van Sonsig (1979), Gesie maak lig (1979), Gesie in Villa Musica (1980) en Gesie in diep water (1981) - word deur onder andere 'die tema van harde werk om veral armoede die hoof te bied' gekenmerk (Wybenga 2005:447). Van Rooyen publiseer later Die duiwe van Botala (1993), wat oor die armoede van 'n 'swart' kind as protagonis' handel (Wybenga 2005:449). Ander jeugromans oor 'bruin' of 'swart' karakters se armoede is Die Sakmense (1985) deur Maretha Maartens, Elk vir mekander (1991) deur Nel Swart, Karoo-Kantate (2013) deur Marié Heese en Van Manenberg met liefde (2014) deur Mike Michael, 'n vertaalde werk.

Du Plessis se studie (1999) oor 'rasseverhoudinge' in SuidAfrikaanse jeugliteratuur is relevant vir hierdie artikel. Dit behels 'n statistiese naspeuring van die representasie van 'wit' en 'swart' (hoof)karakters. Haar bevindings sluit die feit in dat 'gekleurde' karakters (veral volwassenes) in Afrikaanse jeugliteratuur as ondergeskik aan 'wit' volwassenes en hulle kinders uitgebeeld word. Beide Afrikaanse en Engelse jeugliteratuur skep die indruk dat 'swart' mense nie bevoeg is om hulle eie omstandighede te verbeter sonder dat daar telkens deur 'wit' karakters ingegryp word nie (Du Plessis 1999:108-113). In die meeste van die gekose romans vir hierdie artikel word dit duidelik dat 'swart' karakters hoofsaaklik as afhanklik van 'wit' karakters uitgebeeld word. Dit herinner aan Frankenberg (in Willoughby-Herard 2015:45) se verwysing na 'static "suffering bodies"' waarmee witheid onlosmaaklik verbind is.

In sy studie oor die reprensentasie van die 'plaas, dorp en stad' in die Afrikaanse prosa, vind Van Coller Roepman 'n tipiese voorstadroman: 'Weer staan armoede, ongeletterdheid, sedelike verval, geweld en drankmisbruik sentraal in hierdie beskrywing van die lewe van spoorwegwerkers' (Van Coller 2006:105). Bestaande navorsing oor die res van die jeugromans wat in hierdie artikel ontleed word, wentel egter nie om die stadsmilieu of die karakters se armoede nie.

Shezi (1999) ondersoek die manier waarop rasseverhoudinge in romans soos Droomwa uitgebeeld word, terwyl Venter (2005) die 'kontroversiële temas' in Barrie Hough se jeugverhale bestudeer. Volgens Nieman en Hugo (2004:7, 11) is Jacques in Die optog van die aftjoppers 'n voorbeeld van 'n manlike hoofkarakter wat nie tradisionele manlike eienskappe vertoon nie. Merts (2009) sluit Die optog van die aftjoppers in haar studie oor die 'terapeutiese rol' van jeugliteratuur in. Van Zyl (2006) stel ondersoek in na die liminale karakters en ruimtes wat in Vaselinetjie gerepresenteer word, terwyl Spies (2014) en Feinauer en Lourens (2017) onder andere die proses van die vertaling van Vaselinetjie uit Afrikaans in Engels ontleed. Roets (2008) vergelyk 'n Nederlandse roman, Winterijs (2001), en Roepman (2004). Adendorff en Van Dyk (2014) ontleed die transponering van Roepman van roman na film, en Jansen (2015) se studie oor stedelike huiswerkers in Suid-Afrikaanse stadsromans sluit 'n analise van die huiswerker Gladys (die hoofkarakters se huishulp) in Roepman in. Rhebergen en Human (2015:47, 52, $55,56,57,62)$ staan krities teenoor die stereotipiese uitbeelding van gay karakters in Lien se lankstaanskoene, maar Geldenhuys en Anker (2018:366) sonder Lien in laasgenoemde roman uit as een van 'n paar 'geslaagde, sterk vroulike hoofkarakters' in Afrikaanse jeugromans.

Die bekendste eietydse 'volwasse' roman oor 'wit' armoede is waarskynlik Triomf (1994) deur Marlene van Niekerk. In hierdie teks word daar na die gesin verwys as 'die Ampie van die nineties en sy mense wat in Triomf woon' (Van Niekerk 1994:289). Willoughby-Herard (2003:472) lees Triomf as 'n teks wat 'wit' armoede verpolitiseer 'with the intention of disrupting and dismantling the privileged elite debate over whiteness'. Ander romans oor 'wit' armoede sluit in: Stinkafrikaners (2000) deur Tom Dreyer, Aan die ander kant van die stad (2003) deur Herman Wasserman, Jo'burg, die blues en 'n swart Ford Thunderbird (2003) deur Vincent Pienaar, asook ' $n$ Pawpaw vir my darling (2002), en Ons is nie almal so nie (2004) deur Jeanne Goosen. Van Coller (2006) ontleed die stadsmilieu van hierdie romans (binne die stad- en plaas-dialektiek), maar armoede en 'witheid' is nie die fokus van sy studie nie. Dit geld ook ander bestaande studies oor die romans. 


\section{Die representasie van 'wit' armoede in Afrikaanse jeugromans}

Die merkers van 'wit' armoede in die gekose Afrikaanse jeugromans is die beskrywing van karakters, hulle optrede en dialoog asook die ruimte waarin hulle hul bevind. Hoewel vertelperspektief in beginsel 'n verdere merker sou kon wees ('n ek-verteller of derdepersoonverteller wat deur middel van bykomende opmerkings verseker dat die leser die 'wit' karakters as arm interpreteer) is hierdie verskynsel nie in die geselekteerde ses romans ten opsigte van die vertelling waargeneem nie.

\section{Beskrywing}

Die karakters se voorkoms is nie altyd noodwendig 'n merker van hulle armoede nie. In Droomwa troos Paul sy ma deur te sê: 'Moenie worry nie, Ma. Al is ons arm, ons lyk ryk' en 'Flentergatte kan nie 'n Buick ry nie' (Hough 1990:39). Sekere beskrywings kan op hulle armoede dui, soos die 'pienk japon met 'n gat op een elmboog' (Hough 1990:36) wat Paul se ma aanhet, maar daar is ook ander interpretasiemoontlikhede. Dieselfde geld haar 'stukkende lap-pantoffels waarmee sy die kombuis geverf het' (Hough 1990:41). Al het die karakters in Droomwa baie besittings, moet hulle sommige, soos 'n Pierneef-skildery en uiteindelik hulle Buick verkoop. Die 1948 Buick Special is vir die grootste deel van die roman 'n manier waarop die drasties veranderde finansiële situasie van die gesin verbloem word.

Die hoofkarakter in Die optog van die aftjoppers, Jacques, is oorgewig en die klere wat hy aantrek, verklap nie sy armoede nie (Weideman 1994:67, 95 en 98). Die Kaapstadse straatkinders wat omtrent dieselfde ouderdom as Jacques moet wees, lyk baie ouer (Weideman 1994:94). Die deelnemers aan die optog neem egter 'n verwaarloosde voorkoms aan met die doel om geld in te samel (Weideman 1994:98 \& 99).

Vaselinetjie se armoede word gesinjaleer sodra sy 'n stel tweedehandse skoolklere moet dra (Von Meck 2004:28). Die feit dat sy min besittings het, is hoofsaaklik 'n kenmerk van die kinderhuis waarin sy bly. Vaselinetjie merk op hoe die res van die skool die kinderhuiskinders, veral die seuns, behandel. Wanneer hulle in die skoolsaal vergader, sien Vaselinetjie 'hoe die hoof veral die Peppies aangluur' aangesien hulle maklik herkenbaar is met 'die skool se ou uniform van grys hemde' (Von Meck 2004:67).

In Roepman besit die hoofkarakters nie ' $n$ huis nie (hulle huis behoort aan die spoorweë) en hul besittings is minimaal. Braam moet byvoorbeeld op ' $n$ opvoubed in die gang slaap, sy ouers moet skuld aangaan om vir hom en sy broer en susters verjaardaggeskenke te koop en Timus kry nie 'n rugsak wanneer hy sy arm(s) breek nie (Van Tonder 2004:20 \& 82). Die gesin se armoede word met verwysing na ryk karakters se besittings geillustreer, insluitende hul familie, soos Timus se tante wat altyd mooi lyk en baie geld het (Van Tonder 2004:13 \& 27).
Hoewel Lien (in Lien se lankstaanskoene) aanvanklik 'n naskoolse werk kry en dan later by die verkeerslig begin bedel omdat sy geld spaar om ná matriek onmiddellik oorsee te gaan, beteken haar ma se alkoholisme dat Lien gaandeweg haar spaargeld moet gebruik om kos, skoolverwante uitgawes soos nuwe sporttoerusting vir Braam (haar broer) asook die woonstel se huur te dek. By die verkeerslig maak Lien kennis met arm 'wit' bedelaars (Magriet, Roos, en Johnny) en Tibbey, 'n 'swart' bedelaar. Roos is bruingebrand (Van der Walt 2008:84), en al hierdie bedelende karakters se ou, verbleikte klere dui hulle armoede aan. Dit is daarom dat Lien 'n ou rok van haar ma aantrek in 'n poging om soos 'n vrou wat bedel te lyk en haar jeugdige voorkoms met 'n pruik en bril verdoesel (Van der Walt 2008:83-84).

Die armoede van Elmien en die inwoners van die plakkerskamp in Iewers vlieg daar fairy dust, word nie hoofsaaklik deur hulle voorkoms uitgebeeld nie. Elmien en haar twee niggies probeer juis om nie arm voor te kom nie. Elmien weier aanvanklik die uitnodiging om na Rex se partytjie te gaan, omdat sy nie vervoer of gepaste klere het om aan te trek nie (Haasbroek 2014:30-31). Later gebruik sy wel haar spaargeld om klere vir haarself en haar niggies te koop, sodathullenie soos 'freaks' en 'regteegte deernisgevalle' (Haasbroek 2014:96) lyk nie. Elmien se ouma word in vergelyking met dié ryk karakters beskryf met verwysing na haar goedkoop haarkleursel en haar sigarette, twee dinge waarop sy altyd sal geld uitgee (Haasbroek 2014:37). Die arm karakters se besittings word ook met die ryk karakters s'n vergelyk, soos met Rex toe hy 'n motor vir sy verjaardag present kry (Haasbroek 2014:163).

In die meeste van die romans is 'n (gebrek aan) kos nie noodwendig 'n merker van die karakters se armoede nie. Behalwe die karakters in Vaselinetjie en in 'n sekere mate Lien se lankstaanskoene, ly die karakters nie in die res van die romans honger nie. Hulle armoede word eerder deur die tipe kos wat vir hulle beskikbaar is, geillustreer. In Roepman word goedkoper alternatiewe eerder aangeskaf (Van Tonder 2004:24 \& 141). Gekookte maaltye word op 'n gereelde basis deur ouer vroue wat ook in hulle woonstelblok bly in beide Droomwa (Hough 1990:31) en Lien se lankstaanskoene (Van der Walt 2008:19) aan die gesin voorsien en in Die optog van die aftjoppers ontvang die hoofkarakters elke maand 'n slagskaap van oom Matt (Weideman 1994:12). In Iewers vlieg daar fairy dust, eet die gesin slegs twee keer per week vleis (Haasbroek 2014:159).

\section{Optrede}

Sekere karakters se optrede weerspieël 'n poging om hulle huidige lewenstandaard vol te hou. In Droomwa pas Anna (Paul se ma) haar optrede en voorkoms aan om die kunsafslaer te beïndruk in 'n poging om die Pierneef-skildery vir meer geld te verkoop (Hough 1990:38-41).

In Die optog van die aftjoppers en Lien se lankstaanskoene gee die karakters wat nie drastiese armoede ervaar nie voor, met die doel om geld in te samel. In Die optog van die aftjoppers kies 
Jacques aanvanklik om vir sy eie gewin te bedel. Hy reël 'n optog om geld in te samel, met die doel om die entrepreneurskompetisie te wen. Dit wil voorkom asof Jacques nie die ware erns in die ander arm karakters se situasies raaksien nie. Die ander karakters se armoede is vir Jacques oorkombaar, wat sy gesin in staat stel om tot hulle redding te kom. Lien is besig om armoede te perform wanneer sy haar vermom en by 'n verkeerslig staan en bedel met die doel om simpatie by die motoriste te ontlok. Dit is opvallend dat Lien dink almal speel soos sy toneel. Sy gee byna teësinnig toe dat Magriet se rok regtig gaar is van armoede (Van der Walt 2008:132). Die ander bedelaars gee wel voor met die doel om soveel geld as moontlik vir oorlewing te verseker (Johnny maak asof hy blind is, terwyl Tibbey voorgee om 'n Bloubul-ondersteuner te wees), maar hierdie karakters het veel minder moontlikhede tot hulle beskikking as Lien. Lien se optrede in die skool se toneelstuk (Van der Walt 2008:202) versterk die feit dat sy in wese net toneelspeel wanneer sy bedel.

Die hoofkarakter in Vaselinetjie se optrede word hoofsaaklik deur die kinderhuis beïnloed. Sy weerhou haarself wel daarvan om gereeld kollekteeroproepe na haar grootouers te maak, aangesien dit hulle te veel geld kos (Von Meck 2004:36 \& 77).

In Roepman word van karakters verwag om 'wit' te leef, om as deel van die 'wit' samelewing gesien te word. Wanneer die karakters nie hierin slaag nie, word hulle gemarginaliseer en as minderwaardig beskou en hanteer. Alhoewel die patriarg, Abraham, deur sy geloof en politiese oortuigings gelei word, speel armoede uiteraard ' $n$ rol in die manier waarop hy sy gesin regeer. Dit is byvoorbeeld vir hom problematies wanneer Timus sy arm breek, omdat Timus hom nie meer kan help om die bome af te sny nie (Van Tonder 2004:24).

In Iewers vlieg daar fairy dust probeer die arm karakters, veral Elmien, om hulle armoede te oorkom. Elmien het verskeie naskoolse werke, eerstens by 'n videowinkel en later by 'n biblioteek en 'n apteek (Haasbroek 2014:16, 208 \& 210), terwyl haar ouma by 'n groentewinkel werk (Haasbroek 2014:37). Elmien probeer ook om haar skoolwerk betyds te voltooi, aangesien hulle nie (aanvanklik) elektrisiteit het nie, en sy vir die meerderheid van haar skoolloopbaan beperkte tyd gehad het om haar huiswerk te doen of te leer. Sommige karakters soos Temba en Ruan 'weet hoe om krag te tap' (Haasbroek 2014:55) en gebruik dit om die toestelle (wat hulle verkoop) reg te maak en hulle huiswerk te doen, terwyl ander karakters hierdie onwettige praktyk afkeur (soos Temba se ma en die maatskaplike werker) (Haasbroek 2014:71 \& 183). Elmien is ook afhanklik van oom Bok vir 'n rygeleentheid tussen die plakkerskamp en die videowinkel. Al wil hy haar seksueel misbruik, laat sy dit nie toe nie en dring daarop aan om hom met geld te betaal (Haasbroek 2014:111-112). Hy verloor uiteindelik sy geduld en probeer haar op 'n aand seksueel aanrand in die ablusieblok (Haasbroek 2014:140-143). Nie almal in die plakkerskamp kan luukshede soos elektrisiteit bekostig nie, maar karakters deel wel onder mekaar: 'Tannie Poppie is nie suinig met haar krag nie, omtrent almal in die kamp laai hulle selfone by haar' (Haasbroek 2014:67) en wanneer 'n belangrike rugbywedstryd uitgesaai word, laat die mense met voorafbetaalde krag die ander toe om saam te kyk (Haasbroek 2014:139).

\section{Dialoog}

In die romans word die karakters se armoede direk deur hulle dialoog geillustreer wanneer die hoofkarakters met mekaar en ander karakters daaroor gesprekke voer. In Droomwa is voorbeelde hiervan die gesprekke tussen Anna en haar kinders oor die woonstel waarheen hulle moet trek, wanneer sy na haarself as 'n 'kerkmuis' verwys en met Joseph wanneer sy vir hom sê dat sy hom nie sal kan betaal om die Buick te was nie omdat sy 'arm' is (Hough 1990:24, 25 \& 37). In Vaselinetjie sê die karakter Killer aan Vaselinetjie dat die kinderhuiskinders 'Peppies' (as gevolg van hulle kleredrag, bekostigbare klere van Pep Stores) genoem word (Von Meck 2004:27). Die gesprekke wat die karakters in Lien se lankstaanskoene met mekaar voer, dui op hul armoede, soos wanneer Christien (Lien se ma) opmerk hoe duur kruideniersware geword het (Van der Walt 2008:82). Dit is egter ironies, aangesien Christien 'n alkoholis is wat wel geld vind om drank te koop. 'n Gebrek aan dialoog in die vorm van onwilligheid om oor armoede te praat, is ook sigbaar in hierdie roman wanneer Lien ontwykend is oor die gesin se armoede in haar gesprekke met haar vriende, Wouter en Miemie (Van der Walt 2008:19 \& 124). In Iewers vlieg daar fairy dust voel Elmien dat sy en die 'ryk kinders' sal niks hê om oor te praat by Rex se partytjie nie (Haasbroek 2014:82-83). Wanneer Elmien ' $n$ beurs aangebied word, meen Dr. Steyn: 'Dis ook 'n manier om almal te laat agterkom hoe swaar mense in plakkerskampe kry' (Haasbroek 2014:215). Laastens is die name wat Elmien aan haarself en die inwoners van die plakkerskamp gee, 'n merker van hulle armoede: 'plakkerskampprinsesse', 'deernisgevalle', 'freaks', 'losers', '” kindvan'nplakkerskamp', 'flenterprinses', 'plakkerskampkind' en 'plakkerskampmeisies' (Haasbroek 2014:93, 108, 134, 137, $161,165,167)$.

\section{Ruimte}

Ruimte is 'n belangrike merker van armoede in die gekose romans. 'n Woonstel in Hillbrow (Droomwa en ten dele Vaselinetjie), 'n spoorweghuis (Die optog van die aftjoppers en Roepman), 'n kinderhuis (Vaselinetjie) of selfs 'n woonstel in 'n minder gegoede area in Pretoria (Lien se lankstaanskoene) en 'n 'plakkerskamp' (Iewers vlieg daar fairy dust) sinjaleer 'n sekere vlak van armoede. Binne hierdie geografiese ruimtes word die karakters se huishoudelike ruimtes as armoedig uitgebeeld. Die aandag word onder andere geplaas op vaal en min meubels, min vertrekke, stukkende hangkaste, opvoubeddens en leë yskaste. In sommige gevalle word die ruimtes (tesame met besittings) waarvan afstand gedoen moes word, eksplisiet genoem (Droomwa, Vaselinetjie en Lien se lankstaanskoene).

In Droomwa het die gesin voor die afsterwe van Hannes, Paul se pa, in 'n groot huis in Aucklandpark gewoon (Hough 1990:26). In teenstelling met die huis in Aucklandpark is die 
woonstel in Hillbrow baie kleiner; die karakters moet kamers deel, hulle het nie meer 'n erf nie en Pieter moet van iemand anders se donkerkamer gebruik maak (Hough 1990:25 \& 53). Hillbrow is 'n ruimte wat in Droomwa met armoede geassosieer word en as "n goddelose plek, met al die immigrante daar' (Hough 1990:62) gesien word. 'n Vriend van Paul se pa beweer 'goeie Afrikaners behoort nie daar te bly nie' (Hough 1990:62).

In Die optog van die aftjoppers troon Kasteelheuwel (waar luukse huise en tuine agter hoë mure skuil), letterlik bo die spoorwegbuurt, Eerstekamp uit, waar die huise eenders lyk en almal die erwe van die straat af kan sien (Weideman 1994:6). In teenstelling met die spoorwegkamp, het die nabygeleë plakkerskamp nog minder geriewe en ruimte vir bestaan. Jacques noem dat die plakkershutte teenaan die straat gebou is en oral is mense besig met daaglikse take of is in groepies aan die gesels (Weideman 1994:75-77). Die verskil word uiteindelik volledig duidelik wanneer die 'aftjoppers' deelneem aan die optog en hulself op dié manier vir die ander welvarende karakters sigbaar maak.

Die huis van Vaselinetjie se ouma en oupa word voorgestel as een waarin sy die nodige het om psigologies en fisiek te oorleef (Von Meck 2004:35). Hierdie ruimte word met die kinderhuis gekontrasteer, wat as 'n gehawende ruimte beskryf word (Von Meck 2004:19, 21). Die beknopte slaapsaal met gehawende hangkaste suggereer skielik en onweerlegbaar vir Vaselinetjie dat sy haar in 'n drastiese ander omgewing, in 'n 'nagmerrie' bevind. Die kamers is klein en daar is min personeel wat na hulle omsien (Von Meck 2004:24). 'n Ander ruimte wat 'wit' armoede in die roman voorstel, is Hillbrow, waarheen Puck en Vaselinetjie in 'n stadium wegloop (Von Meck 2004:63). Maud (Puck se ma) se klein, beknopte woonstel in Hillbrow is in 'n vuil woonstelblok met donker trappe 'waarvan die mure vol graffiti gespuitverf is' (Von Meck 2004:79, 81).

Daar is ' $n$ duidelike verskil tussen die verskillende buurte in Roepman. Die spoorweghuise waar die hoofkarakter se gesin woon, is 'in 'n gat' waar dit gou donker word (Van Tonder 2004:25). Timus se klasmaat 'Kenneth Shaw [se] huis sit hoog op die bult onderkant Bluffweg. Ryk mense met twéé lakens op elke bed' (Van Tonder 2004:174). Die dogters en seuns moet onderskeidelik 'n kamer in die spoorweghuis deel en saam bad. Nadat ouma Makkie by hulle intrek, meen Timus dit gaan nog 'erger: Braam moet in die gang slaap en ek by Ma-hulle in die kamer' (Van Tonder 2004:20). Aan die einde van die roman verander die gesin se vlak van armoede op grond van die ruimte waarna hulle verhuis. Alhoewel hulle in 'n ander spoorwegkamp gaan bly, is hulle nuwe huis 'darem in 'n goeie straat: waar die ingenieurs se huise is' (Van Tonder 2004:195). Minder gesinslede trek saam na hierdie huis, wat verseker dat daar meer ruimte vir die res gaan wees.

In Lien se lankstaanskoene is dit vir Lien problematies dat hulle van 'n groot huis in 'n ryk buurt van Pretoria na 'n woonstel in 'n eenvoudiger buurt moes trek en in die proses hulle huis, motor en troeteldiere verloor. Die gesin voel vasgekeer in die woonstel en die gebrek aan 'n uitsig is vir hulle steurend (Van der Walt 2008:3 \& 64). Die ruimte dra ook moontlik by tot Lien se optrede, aangesien sy nie die beperkte spasie waarin haar gesin moet oorleef, kan duld nie. Wanneer Lien by Miemie vir die naweek gaan kuier, is haar vriendin se kamer 'so groot soos hulle hele woonstel' (Van der Walt 2008:68). Lien dink gedurig terug aan hul ou lewe, soms met verontwaardiging (Van der Walt 2008:174):

Dis mos nie veronderstel om só te wees nie. Dis asof sy na twee jaar nog steeds hoop sy droom. Sy gaan nog een oggend wakker word met die honde wat op haar bed spring en haar ma wat roep dat hulle vanoggend ontbyt langs die swembad eet.

In Iewers vlieg daar fairy dust bly die karakters in 'n plakkerskamp: 'Hier leef ons letterlik binne in mekaar se gesigte' en die skuilings waarin die arm karakters woon:

... kan enigiets van 'n geroeste karavaan tot 'n paar stukke skadunet oor vier houtpale wees. Wendyhuisies, soos die een wat ek met my ouma en my twee niggies deel, word op Plot 717 as upperclass beskou. (Haasbroek 2014:8)

Elmien droom ook van haar toekomstige huis met haar eie badkamer (Haasbroek 2014:179). Die kinderhuis waarheen Elmien teen die einde van die roman trek, word in vergelyking met die plakkerskamp (en die kinderhuis in Vaselinetjie) as luuks uitgebeeld (Haasbroek 2014:208 \& 217).

\section{'Wit' bevoorregting te midde van 'wit' armoede}

Die karakters in die romans behoort (in wisselende mate) tot die minderheid van 'wit' mense in Suid-Afrika wat nie van 'n hoë lewenstandaard verseker is nie. Die romans demonstreer Lopez (2005:18) se stelling dat nie alle 'wit' mense dieselfde voorregte geniet nie. Die representasie van 'wit' karakters se armoede staan egter in al ses romans in kontras met die geleenthede, besittings, ensovoorts wat hulle as gevolg van hul velkleur geniet.

Hierdie artikel het nie ten doel gehad om die interaksie tussen 'wit' karakters en 'swart' of 'bruin' karakters in die romans te ontleed nie. ${ }^{4}$ Dit is egter opvallend dat die arm gesin in die spoorweghuis in Roepman'n voltydse huiswerker, Gladys, het wat (vanselfsprekend) armer as haar werkgewers is. In Droomwa en Die optog van die aftjoppers is die verlies van 'n huiswerker ' $n$ teken van armoede, en ook by implikasie in Lien se lankstaanskoene. 'Swart' ruimtes in hierdie romans word armoediger as arm 'wit' ruimtes uitgebeeld (behalwe die ryk 'swart' gesin in Die optog van die aftjoppers). Joseph se woonkwartiere in Droomwa het slegs twee klein venstertjies en geen klerekas nie (Hough 1990:76). Dit is moontlik om deur hierdie indirekte vergelyking met Paul se gesin tot die gevolgtrekking te kom dat die gesin deur hulle 'witheid'

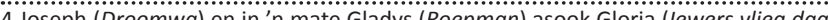
fairy dust), tree as ouefigure of radgewers vir 'wit' karakters op. In Droomwa fairy dust), tree as ou in 'n mate Gladys (Roepman) asook Gloria (lewers vieg daer Roepman, post-apartheidromans wat oor die apartheidsera besin, is die bevraagtekening van die 'wit' karakters se optrede teenoor 'swart' karakters belangrik. 
verseker is van 'n sekere lewenstandaard wat nie vir 'swart' karakters beskikbaar is nie. In Roepman bestaan Gladys se kamer op die gesin se erf uit een vertrek en het geen warm water nie (Van Tonder 2004:10). 'Swart' karakters is besonder weerloos in die roman, soos wanneer Beauty ('n huiswerker in die spoorwegkamp) deur 'n 'swart' man, Elias, aangerand word (Van Tonder 2004:61-62) en Gladys onregverdig deur Timus se ouers behandel word (vgl. Jansen 2015:240-241).

Heel in die begin van Die optog van die aftjoppers word daar gesuggereer dat 'swart' mense in die nuwe demokratiese Suid-Afrika verantwoordelik is vir 'wit' mense se werkloosheid. Terwyl die karakters 'n toets oor beroepsverwagtinge moet voltooi, word die volgende gesprekke gevoer:

'Jy moet 'n brein van 'n Einstein hê om 'n beurs te kry', sê iemand, 'wat nog te sê wérk?' Nog een brom iets oor die kleur van jou vel. (Weideman 1994:2)

In Iewers vlieg daar fairy dust droom Elmien heimlik daarvan om 'n dokter te word. Daar word gesinspeel op diskriminasie teenoor 'wit' mense wanneer sy later byvoeg: 'Dat ek, plakkerskampkind wat ek is, my hart gesit het op een van die moeilikste beroepe wat ' $n$ wit kind op die oomblik in SuidAfrika kan kies' (Haasbroek 2014:82). Later in die roman kry Elmien egter wel ' $n$ beurs om medies te studeer.

In veral Die optog van die aftjoppers, Lien se lankstaanskoene en Iewers vlieg daar fairy dust is dit opvallend dat dit meestal 'wit' karakters is wat tot 'swart' karakters se redding kom, 'n feit wat aan Du Plessis (1999:42) se vroeëre bevinding oor post1994 Afrikaanse jeugliteratuur herinner. Jacques reël die optog om geld in te samel vir straatkinders en Lien help Tibbey om sy onafhanklikheid na sy ongeluk terug te kry deur 'n gespesialiseerde rolstoel vir hom te laat maak en te verseker dat hy steeds sy blyplek kan behou (Van der Walt 2008:159-164 \& 166). Alhoewel hy weer by die verkeerslig bedel, sou hy nie sonder haar hulp tot dié mate kon herstel het nie. Ruan leer Temba om verskeie toestelle reg te maak.

Dit is veelseggend dat die karakters teen die einde van sommige romans nie meer in hulle aanvanklike armoede verkeer nie. Alhoewel sommige gesinslede aan die einde van Roepman na 'n ander spoorweghuis trek, word hul armoede nie meer so drasties voorgestel nie. Daar is minder karakters wat in die huis moet woon met die gevolg dat hulle geriefliker sal leef (Van Tonder 2004:195). Hulle sosiale status verander ook, aangesien hulle na die straat waar die ingenieurs woon, trek. In Lien se lankstaanskoene is die gesin aan die einde van die roman gelukkiger, gaan hulle met vakansie, is dit vir Lien moontlik om by die Universiteit van Pretoria te gaan studeer, en is haar pa uit die tronk vrygelaat (Van der Walt 2008:207-208). Elmien (Iewers vlieg daar fairy dust) trek na 'n kinderhuis, waar haar ryk ouma (dr. Steyn) vir haar sorg en die beurs wat sy ontvang haar in staat stel om medies te gaan studeer. Elmien se afwesigheid in die plakkerskamp sal verder verseker dat haar ouma en twee niggies gemakliker lewe met meer kos en spasie tot hulle beskikking.

\section{Die diskoers oor 'wit' armoede}

Volgens Rosaldo (1989:108) is nostalgie 'a particularly appropriate emotion to invoke in attempting to establish one's innocence and at the same time talk about what one has destroyed'. Hierdie onskuld word dan ook op 'n moontlik skadelike wyse bevestig deurdat die nostalgiese representasie van 'n traumatiese verlede op die aangename aspekte in plaas van die onregte fokus. Nogtans kan nuwe insigte oor 'n traumatiese verlede verkry word deur 'n geskiedkundige gebeurtenis op 'n nostalgiese wyse te representeer. In Droomwa en Roepman word 'n Afrikaanse gemeenskap verbeel wat solidariteit te midde van armoede en swaarkry ken. Deur dit na die verlede te verplaas, kan iets waargeneem word oor die meer homogene Afrikanergemeenskap wat die skrywer dalk in die hede sou wou sien. Die nostalgiese uitbeelding van die verlede, waardeur armoede op 'n verromantiseerde wyse uitgebeeld word, is aan die einde van Roepman duidelik:

Van hier af kan mens die hele shunting yard sien: lokomotiewe, elektriese units, rye en rye trokke. Daar is g'n vrag in die trokke nie, almal leeg, al die jare, en daar word ook nie iets ingelaai nie. Hulle word net heeltyd rondgeshunt. Die shunters het walkietalkies en iemand in 'n kantoor sê vir hulle hoe hulle die trokke moet shunt, van dié sylyn af na daai een toe, tot die trokke 'n trein is wat gehaak word en hier moet weg, nog steeds leeg, agter die lokomotief aan. Die trokke gaan net saam. Al wat hulle moet doen, is om aangehaak te bly, hulle sal daar kom waar die waybills wat aan hulle vas is, sê waar hulle moet heen (Van Tonder 2004:197-198).

In die laaste twee sinne is die treine ' $n$ subtiele metafoor vir die werkersklas-Afrikaners waaroor Roepman handel: solank hulle 'aangehaak' bly aan die norme van die Staat en die Kerk, is hulle van 'n sekere mate van stabiliteit verseker. In Droomwa en Roepman is daar 'n verromantiseerde beeld van 'eenvoudige Afrikaners', gewone mense wat die onwetende en onwillige slagoffers van politieke stelsels is, en tog meer moreel uit die verf kom as ryk Afrikaners. Bogenoemde tweeledige funksie van nostalgie funksioneer op 'n opvallende wyse in Hough en Van Tonder se romans: daar is sprake van 'n verlede wat as harmonieus in kontras met die eietydse situasie uitgebeeld word. Mikhail Bakhtin noem hierdie verskynsel 'historical inversion' wat daarop dui dat die 'ideal that is not being lived now is projected into the past' (in Hutcheon \& Valdas 1998:20). Die funksie van die armoede in Vaselinetjie is hoofsaaklik om die ironie van apartheidswetgewing (en die nagevolge daarvan) te belig; die 'wit' karakter sou nie in armoede leef indien sy eenvoudig by haar 'bruin' aangenome ouers kon bly nie.

Die oorblywende romans het egter die feit gemeen dat 'wit' armoede problematies uitgebeeld word. Dit word nie op subversiewe wyse verpolitiseer nie (vgl. WilloughbyHerard 2003:472); die romans suggereer eerder dat dit onaanvaarbaar is vir 'wit' mense om in armoede te leef (ook Droomwa, Roepman en Vaselinetjie is ten dele skuldig hieraan). Lien se gefrustreerde uitspraak, 'Dis mos nie veronderstel om só te wees nie' (Van der Walt 2008:174) sou deur al die 'wit' karakters in al die romans geuiter kon gewees het. 
Kreatiewe oplossings moet bedink word vir karakters om uit hulle subjektiewe armoede te ontsnap - Lien se bedelary in Lien se lankstaanskoene is die vernaamste voorbeeld hiervan. Die 'swart' meerderheidsregering word op 'n subtiele wyse die skuld gegee vir die vermeende gebrek aan ontsnappingsmoontlikhede vir karakters in Die optog van die aftjoppers en Iewers vlieg daar fairy dust - nogtans slaag veral Lien en Elmien (Iewers vlieg daar fairy dust) daarin om hulle omstandighede te oorstyg en gevorderde opleiding te kry (universiteitstudies). Die wyse waarop veral Lien armoede perform, suggereer dat 'wit' karakters nie onomkeerbaar aan armoede uitgelewer is nie. Haar bedelary en Jacques se optog in Die optog van die aftjoppers vervorm armoede tot iets vermaakliks en bowenal tydelik vir 'wit' karakters.

Die feit dat die romans wat in hierdie artikel bestudeer is ' $w i t^{\prime}$ armoede as hooftema het (met die moontlike uitsondering van Vaselinetjie), impliseer dat 'wit' armoede ' $n$ wesenlike probleem vir 'wit' Afrikaanssprekendes is. Daar is byvoorbeeld eksplisiete verwysing na die bewuswording ten opsigte van 'wit' mense wat in plakkerskampe woon in Iewers vlieg daar fairy dust (Haasbroek 2014:215). Hoe 'n mens ook al armoede definieer, bly 'wit' armoede egter 'n baie beperkte verskynsel in Suid-Afrika. Die ruimte wat aan hierdie randverskynsel afgestaan word, dra by tot 'n diskoers waarin 'witheid' nie op 'n gemaklike wyse aan die vernedering en lyding van armoede blootgestel kan word nie.

\section{Slot}

In hierdie artikel is 'n vergelyking tussen ses Afrikaanse jeugromans getref om die ooreenkomste en verskille in die representasie van 'wit' armoede uit te lig. Armoede kan hoofsaaklik uit die uitbeelding van ruimte afgelei word, asook 'n beskrywing van die karakters, hulle dialoog en optrede. Ten opsigte van ruimte sinjaleer karige meubels, min vertrekke, karakters wat slaapkamers moet deel en sekere geografiese ruimtes armoede. In die meeste van die romans is 'wit' armoede die gevolg van 'n drastiese ommekeer in omstandighede, en die verlies aan vroeëre besittings is ' $n$ vername merker van armoede. Dit is opvallend dat die karakters in die meeste van die romans nié arm lyk nie, 'n feit wat moontlik die subjektiewe aard van hulle armoede belig. Dialoog is 'n merker van armoede in die sin dat karakters hulself dikwels as arm beskryf. Sekere karakters probeer in hul voorkoms en optrede verdoesel hoe arm hulle in werklikheid is, terwyl ander karakters juis op veelseggende wyse armoede perform.

'Wit' bevoorregting te midde van 'wit' armoede blyk, ironies genoeg, uit die representasie van karakters en hul omgewing as arm. Danksy hulle velkleur geniet 'wit' karakters sekere geleenthede, besittings, ensovoorts ten spyte van hul armoede. Die karakters se 'witheid' verleen ook aan hulle die illusie dat hulle, in sommige van die romans, tot die 'swart' karakters se redding moet kom. In Droomwa en Roepman is die funksie van die representasie van 'wit' armoede om 'n verromantiseerde beeld van die apartheidsverlede tot stand te laat kom. 'n Afrikaanse gemeenskap wat steeds solidariteit ken te midde van hulle ekonomiese omstandighede, word ten opsigte van die post-1994 omgewing verbeel. Die ander tekste dra by tot die diskoers oor 'wit' armoede en 'wit' bevoorregting waarin 'witheid' nie met armoede gerym kan word nie.

Die bevindings van die artikel sou aan 'n groter korpus tekste gemeet kon word, en dit sou veral lonend wees om tekste wat vóór 1990 gepubliseer is (Ampie, Gesie, ensovoorts) op vergelykende wyse te betrek. Die gekose jeugromans eindig meestal positief met die karakters se armoede wat verlig word. Gevolgliksou ditinteressanteverderenavorsingsmoontlikhede inhou om die representasie van armoede in 'volwasse' romans te vergelyk met dié in Afrikaanse jeugliteratuur. Eweneens sou 'n vergelyking van die representasie van armoede in Afrikaanse jeugliteratuur en dié in ander tale in Suid-Afrika, met ' $n$ fokus op 'swart' én 'wit' armoede 'n veel vollediger verkenning van die interaksie tussen 'ras' en 'klas' in Suid-Afrikaanse jeugliteratuur tot gevolg hê.

\section{Erkenning}

Hierdie artikel is gebaseer op die M.A.-verhandeling 'Die representasie van 'wit' armoede in Afrikaanse jeugliteratuur' deur Loraine van der Westhuizen wat in 2017 aan die Universiteit van Pretoria voltooi is met Jacomien van Niekerk as studieleier. Baie dankie aan Andries Visagie wat oorspronklik voorgestel het dat die representasie van 'wit' armoede in jeugliteratuur ondersoek behoort te word.

\section{Mededingende belange}

Die outeurs verklaar dat hy geen finansiële of persoonlike verbintenis het met enige party wat hulle nadelig kon beïnvloed in die skryf van hierdie artikel nie.

\section{Outersbydrae}

Beide outeurs het eweredig bygedra tot die skryf van die artikel.

\section{Etiese oorwegings}

Hierdie artikel volg alle etiese standaarde vir navorsing sonder direkte kontak met mens of dier.

\section{Befondsing}

Hierdie navorsing het geen spesifieke toekenning ontvang van enige befondsingsagentskap in die openbare, kommersiële of nie-winsgewende sektore.

\section{Data beskikbaarheidsverklaring}

Data-deling is nie van toepassing op hierdie artikel nie, aangesien geen nuwe data in hierdie studie geskep of ontleed is nie.

\section{Vrywaring}

Die sienings en menings wat in hierdie artikel uitgedruk word, is dié van die outeurs en weerspieël nie noodwendig die amptelike beleid of posisie van enige geaffilieerde agentskap van die outeurs nie. 


\section{Literatuur}

Adendorff, E. \& Van Dyk, A., 2014., 'Die verwerkingsproses ten opsigte van toneelkeuse met verwysing na die rolprent Roepman', LitNet Akademies 11(2), besigtig $24 \mathrm{Me}$ 2019, vanaf https://www.litnet.co.za/die-verwerkingsproses-ten-opsigte-vantoneelkeuse-met-verwysing-na-die-rolprent-roepman/.

Alcock, P., 2006, Understanding poverty, Palgrave Macmillan, New York.

Anon., 1991, “'Droomwa” is beste in jare', Tempo 31 Januarie, 1991, p. 9.

Anon., 2009, 'Lien se lankstaanskoene', Boeke-insig 01 Januarie, 2009, p. 44.

Botha, E., 1999, 'Jochem van Bruggen (1881-1957)', in H.P. van Coller (red.), Perspektief en profiel: 'n Afrikaanse literatuurgeskiedenis, deel 2, bl. 644-652, Van Schaik, Pretoria.

Brümmer, W., 2004, “'Vaselinetjie" sal met jou bly praat', Die Burger, 20 Desember, p. 1.

Cilliers, C., 1990, 'Dolfyne en Droomwa sê Turtles die stryd aan', Rapport, 09 Desember, p. 27.

Cilliers, C., 2005, 'Roepman die hoogtepunt in Van Tonder se oeuvre', Rapport, 06 Februarie, p. 15.

De Waal, S., 1994, 'Facing up to death and loss', Mail \& Guardian, 07 April, p. 46.

Du Plessis, M., 1999, 'Rasseverhoudinge in Suid-Afrikaanse jeuglektuur sedert 1990', M.A.-verhandeling, Potchefstroomse Universiteit vir Christelike Hoër Onderwys, Potchefstroom.

Du Toit, M., 2017, 'lewers vlieg daar fairy dust', PUKU, besigtig 09 Mei 2019, vanaf https://www.puku.co.za/books/iewers-vlieg-daar-fairy-dust/.

Feinauer, I. \& Lourens, A., 2017, 'The loyalty of the literary reviser: Author, source text, target text or reader?' Stellenbosch Papers in Linguistics Plus (SPiL Plus) 53(1) target text or reader?' Stellenbosch Papers in Linguistics Plus (SPiL Plus
97-118, viewed 24 May 2019, from https://dx.doi.org/10.5842/53-0-735

Fransman, T. \& Yu, D., 2019, 'Multidimensional poverty in South Africa in 2001-16', Development Southern Africa 36(1), 50-79.

Garson, P., 1991, 'Hough confronts teenagers with real life', Weekly Mail, 31 October, p. 3.

Geldenhuys, I. \& Anker, J., 2018, 'Die aard van genderuitbeelding van vroulike hoofkarakters in onlangse Afrikaanse jeugliteratuur', Litnet Akademies 15(1), 352-380, besigtig 31 Mei 2019, vanaf https://www.litnet.co.za/die-aardvan-genderuitbeelding-van-vroulike-hoofkarakters-onlangse-afrikaansejeugliteratuur/.

Giliomee, H., 2004., Die Afrikaners: 'n Biografie, Tafelberg, Kaapstad.

Haasbroek, M., 2014, lewers vlieg daar fairy dust, Lapa, Pretoria.

Hambidge, J., 2004, 'Wanneer seuns mans word ... Storie verbeeldingryk en onthutsend uit oë van 'n kind vertel', Volksblad, 01 November, p. 6.

Harper, S., 2009, 'Bekroonde, eietydse jeugboek ook vir ouers', Beeld, 22 Junie, p. 11. Hough, B., 1990, Droomwa, Tafelberg, Kaapstad.

Hough, B., 1994, 'Wenboeke vol verrassings en vreugde', Boeke-Insig, 31 Desember, p. 9.

Hutcheon, L. \& Valdas, M.J., 1998, 'Irony, nostalgia, and the postmodern: A dialogue', Poligrafias 3(1998-2000), 18-41.

Jacobs, J., 2004, 'Vaselinetjie maak jou oë oop', Volksblad, 13 September, p. 6.

Jansen, E., 2015, Soos familie: Stedelike huiswerkers in Suid-Afrikaanse tekste, Protea Boekhuis, Pretoria.

John, P., 2005, 'Kyk weer met die oë van 'n kind', Die Burger, 03 Januarie, p. 9.

Konterdans, J., 1990, 'Bekroonde jeugboeke verskil oor “Nuwe SA": Ergste is pappie se plathand', Vrye Weekblad, 21 September, p. 14.

Le Roux, M., 1990, 'Aantreklik en vlot', Die Burger, 11 Oktober, p. 17.

Le Roux, M., 1994, “'Aftjopper” ware wenner', Die Burger, 14 Desember.

Lipsitz, G., 2006, The possessive investment in whiteness: How white people profit from identity politics, Temple University Press, Philadelphia, PA.

Lopez, A.J., 2005, 'Introduction: Whiteness after empire', in A.J. Lopez (ed.), 2005, Postcolonial whiteness: A critical reader on race and empire, pp. 1-30, State University of New York Press, New York.

McIntosh, P., 1988, 'White privilege and male privilege: A personal account of coming to see correspondences through work in women's studies', Working paper no. 189, Wellesley Centers for Women, Massachusetts.

McIntosh, P., 1989, 'White privilege: Unpacking the invisible knapsack', Peace and Freedom July/August, 10-12, Women's International League for Peace and Freedom, Philadelphia, PA.

McIntosh, P., 2015, 'Extending the knapsack: Using the white privilege analysis to examine conferred advantage and disadvantage', Women \& Therapy $38(3-4)$ 232-245.

Merts, H.M., 2009, 'Die terapeutiese rol van fiksie in die hantering van sekere lewenskrisisse en ontwikkelingsprobleme van kinders', M.A.-verhandeling, Universiteit van Suid-Afrika, Pretoria.

Minervini, R., 1990, 'Capturing the painful territory of childhood', The Sunday Star, 09 December, p. 6
Murphy, T., 2006, 'Characters make this a memoir not easily forgotten', Sunday Independent, 16 July, p. 18.

Nieman, M., 2005, 'Eendag lank, lank gelede, toe daar nog duidelike grense tussen jeug- en volwassene-literatuur was ...', Stilet 17(2), 122-138.

Nieman, M. \& Hugo, A.J., 2004, 'Vrouekarakters in bekroonde Afrikaanse jeugboeke: 'n Opdatering', Tydskrif vir Geesteswetenskappe 44(1), 1-14.

Olivier, F., 2005, 'Lesers oud én jonk verdien meer respek', Beeld, 24 Januarie, p. 13.

Oosthuizen, M.M., 2010, "n Polisistemiese ondersoek na verandering in die Afrikaanse kinderliteratuur-sisteem sedert 1990', M.A.-verhandeling, Universiteit Afrikaanse kinderliteratuur-siste
van Stellenbosch, Stellenbosch.

Rhebergen, J. \& Human, T., 2015, 'Darem meer as moffies? Stereotipering in die voorstelling van homoseksuele en homoseksualiteit in die Afrikaanse jeugliteratuur', LitNet Akademies 12(1),33-65, besigtig 05 April 2019, vanaf http://www.litnet.co.za/Article/darem-meer-as-moffies-stereotipering-in-diehttp://www.litnet.co.za/Article/da
voorstelling-van-homoseksueles.

Roets, K., 2008, "n Vergelykende studie van twee jeugromans: Winterijs (2001) deur Peter van Gestel en Roepman (2004) deur Jan van Tonder', M.A.-verhandeling, Universiteit van Stellenbosch, Stellenbosch.

Rosaldo, R., 1989, 'Imperialist nostalgia', Representations 26(Spring), 107-122.

Shezi, B.K., 1999, 'Vernuwing van maatskaplike norme as tema in Afrikaanse jeugliteratuur vanaf 1985 tot 1995', M.A.-verhandeling, Universiteit van Zululand, Kwadlangezwa.

Spies, C., 2014, 'Die bronteksouteur se bydrae tot die produksieproses van literêre vertalings', Stellenbosch Papers in Linguistics Plus (SPiL Plus) 45(2014), 125-165, besigtig 24 Mei 2019, vanaf http://dx.doi.org/10.5842/45-0-624

Steenberg, E., 1990, "n Verhaal om lank te onthou', Beeld, 22 Oktober, p. 10.

Steenberg, E., 1995, 'Drie wenverhale is ' $n$ geslaagde bydrae tot Afrikaanse jeuglektuur', Beeld, 20 Februarie, p. 6.

Steyn, M., 2001, 'Whiteness just isn't what it used to be. White identity in a changing South Africa.', State University of New York Press, New York.

Sturm, B.W. \& Michel, K., 2009, 'The structure of power in young adult problem novels', Young Adult Library Services 7(2), 39-47.

Swart, K., 2014, 'lewers vlieg daar fairy dust deur Marisa Haasbroek', Litnet Akademies, besigtig 09 Mei 2019, vanaf https://www.litnet.co.za/iewers-vlieg-daar-fairy-dustdeur-marisa-haasbroek/.

Van Coller, H.P., 2006, 'Die representasie van plaas, dorp en stad in die Afrikaanse prosa', Stilet 18(1):90-121.

Van den Hoven, P., 1994, 'Waar de hoofdstroom begint: Van probleemboek naar initiatieroman', in Grensverkeer: Over jeugdliteratuur, pp. 39-57, NBLC, Den Haag.

Van der Walt, B.F., 2012, 'Fiksie vir jong volwassenes (FJV) as selfstandige genre binne die Afrikaanse Letterkunde', M.A.-verhandeling, Universiteit van Pretoria.

Van der Walt, D., 2008, Lien se lankstaanskoene, Tafelberg, Kaapstad.

Van der Westhuizen, C., 2015, 'New Afrikaners are making the trek to inclusivity', Sunday Times, 15 November, p. 22.

Van Niekerk, M., 1994, Triomf, Quillerie, Kaapstad.

Van Tonder, J., 2004, Roepman, Human \& Rousseau, Kaapstad.

Van Wyk, E., 2004, 'A moving tale of innocence lost', Pretoria News, 22 November, p. 9.

Van Zyl, D., 2006, “"Ek is besig om iemand heeltemal anders te word ...": Die ontginning van liminaliteit in Vaselinetjie deur Anoeschka von Meck', Literator ontginning van
$27(7), 39-56$.

Venter, S.E., 2005, 'Kontroversialiteit as tematiese lokmotief in Barrie Hough se My kat word herfs, Droomwa, Vlerkdans en Skilpoppe', M.A.-verhandeling, Universiteit van Johannesburg, Johannesburg.

Vinassa, A., 1991, 'Barry's challenging SA children', The Star, 03 April, p. 12.

Von Meck, A., 2004, Vaselinetjie, Tafelberg, Kaapstad.

Weideman, G., 1994, Die optog van die aftjoppers, Tafelberg, Kaapstad.

West, M., 2009, White women writing white: Identity and representation in (post-) apartheid literatures of South Africa, David Philip, Cape Town.

Wilkinson, K., 2018, 'Factsheet: South Africa's official poverty numbers', Africa check: Sorting fact from fiction, viewed 24 May 2019, from https://africacheck.org/ factsheets/factsheet-south-africas-official-poverty-numbers/

Williams, I., 2014, 'What are YA books? And who is reading them?', The Guardian, viewed 05 April 2017, from https://www.theguardian.com/books/ booksblog/2014/jul/31/ya-books-reads-young-adult-teen-new-adult-books.

Willougby-Herard, T., 2003, 'Waste of a white skin' or civilizing white primitives: The Carnegie commission study of poor whites in South Africa, 1927-1932', Part 1, PhD Thesis, University of California Press, California.

Willougby-Herard, T., 2015, Waste of a white skin: The Carnegie corporation and the racial logic of white vulnerability, University of California Press, California.

Wybenga, G., 2005, 'Engela van Rooyen (1939-)', in G. Wybenga \& M. Syman (reds.), Van Patrys-hulle tot Hanna Hoekom: 'n Gids tot die Afrikaanse kinder-en jeugboek, Van Patrys-hulle tot Hanna Hoekom: ' $n$ Gid
bl. 447-451, LAPA Uitgewers, Pretoria.

Wybenga, G. \& Snyman, M., 2005, Van Patrys-hulle tot Hanna Hoekom: ' $n$ Gids tot die Afrikaanse kinder- en jeugboek, LAPA Uitgewers, Pretoria. 